ISBN 978-93-86878-06-9

9th International Conference on Business, Management, Law and Education (BMLE-17)

Kuala Lumpur (Malaysia) Dec. 14-15, 2017

\title{
Innovative Instructional Strategies Utilized by Professional Education Teachers
}

\author{
Philip G. Queroda \\ Pangasinan State University, Philippines
}

\begin{abstract}
This study was conducted to determine the innovative instructional strategies utilized by Professional Education Teachers in selected HEIs in Pangasinan to cope up with the demands of the 21st century education and somehow alleviate the HEIs goals and objectives as far as instruction is concern.

The descriptive-correlational method of research was used in the study. Purposive sampling-technique was used to select the respondents. The research instrument that was used in gathering the data is a questionnaire. The data gathered were analyzed and interpreted using frequency counts, percentages, mean, and Analysis of Variance (ANOVA).

The faculty members handling professional education subjects possess a high level integrity, decisiveness, resourcefulness, commitment and stress tolerance. They perceived a high level of knowledge and skills of the faculty members of the innovative instructional activities. The degree of utilization of innovative strategies based on the instructional activities supplemented by the faculty members to brain-based instructional strategies is moderate while very low to individualized teaching strategies.

The faculty members have the same level of perceived knowledge and skills of the faculty members on the instructional activities. In the perceived knowledge and skills of the faculty members on the instructional activities is related to the degree of manifestation of the professional characteristics of the faculty members handling professional education subjects. Moreover, there is a significant relationship between the utilization of innovative instructional strategies and level of perceived knowledge and skills of the faculty members of the innovative instructional activities.

Faculty members should further enhance and uphold academic excellence in teaching by continuing their studies to graduate and post graduate courses in relation to professional education. They should also enrich their knowledge and skills to instructional strategies by attending seminars or training related to instructional strategies on a regular basis. They should always set a very high standard of professionalism by demonstrating professional characteristics most especially to integrity, decisiveness, resourcefulness, commitment and stress tolerance. Further, they should have an advocacy in updating their knowledge and skills to teaching innovation most especially to instructional activities and strategies. The school should conduct its own seminar relating to innovative instructional strategies carrying out its nature, significance, implications, benefits, issues and concerns.
\end{abstract}

Keywords: Instructional Strategies, Innovative Instructional Activities, Innovative Instructional Strategies, Brain-Based Strategies, Individualized Teaching Strategies

\section{Introduction}

Education is a light that shows the mankind the right direction to surge (Damodharan, 2007). If education fails to inculcate self-discipline and commitment to achieve in the minds of the student, it is not their fault. Education should be converted into sport and the process of learning should be interesting and fun to motivate learners to stay on track and eventually achieve their goals and objectives in studying. Education must be exciting to them instead of being a problem. It is an essential element of their development and assists them to become responsible individuals. 
In the Philippines, tertiary education or post-secondary schooling is referred to in the Education Act of 1982 as "higher education leading to a degree in a specific profession or discipline." Its objectives are: (1) to provide a general education program that will promote national identity, cultural consciousness, moral integrity, and spiritual vigor; (2) to train the nation's manpower in the skills required for national development; (3) to develop the professions that will provide leadership for the nation; and (4) to advance knowledge through research work and apply new knowledge for improving the quality of human life and responding effectively to changing societal needs and conditions (http://www.chanrobles.com/bataspam bansabilang232.htm\#.UtYRgfvO7Fo).

A perusal of the aforementioned objectives will suffice in indicating the crucial importance of the tertiary level in the educational system (Aquino,1998). It is on this account that better teaching in our colleges and universities should be aimed at.

The literature on college teaching suggests that there is a growing realization that it is best to provide students a variety of learning situations rather than to attempt to develop a standard method of instruction for all courses.

Danielson (2002) stressed that engaging the learners actively in the learning activities is the next challenge for teachers in order to achieve our objectives and eventually our vision-mission statements. We have to give our students opportunities to participate in classroom activities. We have to give varied activities to our learners for "hands-on-minds-on" learning. Researchers found out that the most effective approaches - resulting in $75 \%$ and $90 \%$ retention rates, respectively - are learning by doing (such as through the inquiry method) and learning by teaching others.

On the other hand, Corpuz (2003) added that the more senses that are involved in learning, the more and the better the learning. What is seen and heard is learned more than what is just seen or just heard. This implies that visual aids are more effective than mere audio visual aids. But a combination of audio and visual aids is far more effective. Most effective, of course, is the use of a combination of three or more sense, thus the term "multisensory aids".

The participation of the senses is where the application of strategies will put into place. At the moment, to name a few of the best and current instructional strategies in college teaching are as follows: Lecture/Rhetorical Questioning; Surveys with Exemplifier; Turn to Your Partner and Pause; Halting Time; Guided Lecture; Story Telling and Group Discussion Triggers. (http://teaching.uncc.edu/articles-books/best-practice-articles/coursedevelopment/best-practices).

A comparable list of instructional strategies enumerated by Corpuz and Salandanan (2003), both professional education professors in the Philippines, categorized the strategies as brain-based instructional strategy and individualized instructional strategy.

Various higher educational institutions in Pangasinan manifest their concern in the development of instruction both in private and public. The learning process requires the challenge of new and different experiences, the trying of the unknown, and therefore, necessarily must involve the making of mistakes (Pine, 1990). For people to acquire learning, opportunity is necessary for them to discover latest conditions and conditions without being reprimanded or fined for inaccuracies which are vital to the interest of learning.

Therefore, it is the appropriate time to uncover means to innovate instruction through innovative instructional strategies to cope up with the demands of the 21 st century education and somehow alleviate the HEIs goals and objectives as far as instruction is concern.

\section{- Statement of the Problem}

This study determined the innovative instructional strategies utilized by Professional Education Teachers. Specifically, it answered the following questions: 
1. What is the profile of the faculty members handling Professional Education subjects in terms of highest educational attainment, designation, number of years in handling professional education subjects, number of years in teaching, and seminars attended related to instructional strategies?

2. What is the degree of manifestation of the professional characteristics of the faculty members handling professional education subjects?

3. What is the level of perceived knowledge and skills of the faculty members on the following innovative instructional activities?

4. What is the degree of utilization of innovative strategies based on the instructional activities supplemented by the faculty members?

5. Is there a significant difference in the perceived knowledge and skills of the faculty members on the instructional activities across profile variables?

6. Is there a significant relationship between the perceived knowledge and skills of the faculty members on the instructional activities and the degree of manifestation of the professional characteristics of the faculty members handling professional education subjects?

7. Is there a significant relationship between the utilization of innovative instructional strategies and level of perceived knowledge and skills of the faculty members of the innovative instructional activities?

8. What are the problems encountered by the faculty members in utilizing innovative instructional strategies?

\section{Methodology}

The descriptive-correlational method of research was used in the study. The descriptive research describes the existing conditions to be investigated. According to Calmorin and Calmorin (2006), the descriptive research focuses on the present condition. They provide essential knowledge about the nature of objects and persons. Good and Scates (1972) stressed that descriptive normative surveys frequently made ascertain the normal or typical condition, or to compare local results with a state of the national norm.

Another research method used is an analytical survey which attempts to describe and explain why certain situations exist. In this approach, two or more variables are usually examined to test research hypotheses (http://www.pathways.cu.edu.eg/subpages/training_courses/Research\%20Methods\%208/Ch apter4.htm).

\section{Results and Discussion}

\section{- Profile of Professional Education Faculty}

Out of 69 faculty members, 31 or $44.9 \%$ master's degree holder, 24 or $34.8 \%$ with a doctorate degree and 14 or $20.3 \%$ are bachelors' degree holder. The majority of the faculty members comprising 44 or $63.8 \%$ have very short experience in teaching professional education subjects which are 1-10 years. On the other hand, 2 or $2.9 \%$ are experienced professional education faculty with 21-25 years of handling professional education subjects respectively. There are 29 professional education faculty members or $42 \%$ are in the teaching service for 1-10 years while 23 or $33.3 \%$ of them have $11-20$ years and above and the remaining 17 or $17.6 \%$ have 21 years and above. There are more than half of the faculty, 54 or $78.3 \%$ have a minimal number of seminars attended related to instructional strategies with 1-10 seminars and the least of them with 9 or $13 \%$ attended 21 seminars and above.

- Degree of Manifestation of the Professional Characteristics of the Faculty Members Handling Professional Education Subjects

Overall, the degree of manifestation of the professional characteristics of the faculty members handling professional education subjects is high with an overall mean value of 4.08 . 
In particular, the degree of manifestation of the professional characteristics of the faculty members handling professional education subjects is also high in integrity with 4.37 mean value, decisiveness with 4.19 , and resourcefulness with 4.10 , commitment with 4.08 and stress tolerance with 3.74 .

\section{- Level of Perceived Knowledge and Skills of the Faculty Members of the Innovative Instructional Activities}

In general, the level of perceived knowledge and skills of the faculty members of the innovative instructional activities is high with an overall mean value of 4.289 .

- Degree of Utilization of Innovative Strategies Based on the Instructional Activities Supplemented by the Faculty Members to Instructional Strategies

TABLE I: Degree of Utilization of Innovative Strategies Based on the Instructional Activities Supplemented by the Faculty Members to Brain-Based Strategies

\begin{tabular}{|c|c|c|c|c|c|c|c|c|c|c|}
\hline \multirow[t]{2}{*}{$\begin{array}{l}\text { Brain-Based } \\
\text { Strategies }\end{array}$} & \multicolumn{2}{|c|}{$\begin{array}{r}\text { Very Low } \\
\text { (1-2 Activities } \\
\text { Supplemented) } \\
\end{array}$} & \multicolumn{2}{|c|}{$\begin{array}{c}\text { Low } \\
\text { (3-4 Activities } \\
\text { Supplemented) }\end{array}$} & \multicolumn{2}{|c|}{$\begin{array}{c}\text { Moderate } \\
\text { (5-6 Activities } \\
\text { Supplemented) }\end{array}$} & \multicolumn{2}{|c|}{$\begin{array}{c}\text { High } \\
\text { (7-8 Activities } \\
\text { Supplemented) } \\
\end{array}$} & \multicolumn{2}{|c|}{$\begin{array}{l}\text { Very High } \\
\text { (9-10 Activities } \\
\text { Supplemented) } \\
\end{array}$} \\
\hline & $\mathrm{f}$ & $\%$ & $\mathrm{f}$ & $\%$ & $\mathrm{f}$ & $\%$ & $\mathrm{f}$ & $\%$ & $\mathrm{f}$ & $\%$ \\
\hline Active review & 16 & 23.2 & 14 & 20.3 & 29 & 42.0 & 7 & 10.1 & 3 & 4.3 \\
\hline $\begin{array}{l}\text { Simulations and } \\
\text { Games }\end{array}$ & 17 & 24.6 & 11 & 15.9 & 24 & 34.8 & 13 & 18.8 & 4 & 5.8 \\
\hline Visual Processing & 19 & 27.5 & 18 & 26.1 & 20 & 29.0 & 6 & 8.7 & 6 & 8.7 \\
\hline $\begin{array}{c}\text { Real-life or } \\
\text { Authentic Problem } \\
\text { Solving }\end{array}$ & 17 & 24.6 & 14 & 20.3 & 19 & 27.5 & 8 & 11.6 & 11 & 15.9 \\
\hline Songs, Jingles, Raps & 18 & 26.1 & 27 & 39.1 & 11 & 15.9 & 6 & 8.7 & 7 & 10.1 \\
\hline Hands-on-Activities & 17 & 24.6 & 25 & 36.2 & 11 & 15.9 & 3 & 4.3 & 13 & 18.8 \\
\hline Peer teaching & 14 & 20.3 & 21 & 30.4 & 19 & 27.5 & 11 & 15.9 & 4 & 5.8 \\
\hline Writing Strategies & 24 & 34.8 & 12 & 17.4 & 21 & 30.4 & 7 & 10.1 & 5 & 7.2 \\
\hline $\begin{array}{l}\text { Mnemonic } \\
\text { Strategies }\end{array}$ & 23 & 33.3 & 20 & 29.0 & 15 & 21.7 & 6 & 8.7 & 5 & 7.2 \\
\hline
\end{tabular}

The degree of utilization of innovative strategies based on the instructional activities supplemented by the faculty members to brain-based instructional strategies is moderately innovative.

TABLE II: Degree of Utilization of Innovative Strategies Based on the Instructional Activities Supplemented by the Faculty Members to Individualized Instructional Strategies

\begin{tabular}{|c|c|c|c|c|c|c|c|c|c|c|}
\hline \multirow[t]{2}{*}{$\begin{array}{l}\text { Individualized } \\
\text { Strategies }\end{array}$} & \multicolumn{2}{|c|}{$\begin{array}{r}\text { Very Low } \\
\text { (1-2 Activities } \\
\text { Supplemented) }\end{array}$} & \multicolumn{2}{|c|}{$\begin{array}{c}\text { Low } \\
\text { (3-4 Activities } \\
\text { Supplemented) }\end{array}$} & \multicolumn{2}{|c|}{$\begin{array}{c}\text { Moderate } \\
\text { (5-6 Activities } \\
\text { Supplemented) } \\
\end{array}$} & \multicolumn{2}{|c|}{$\begin{array}{c}\text { High } \\
\text { (7-8 Activities } \\
\text { Supplemented) }\end{array}$} & \multicolumn{2}{|c|}{$\begin{array}{l}\text { Very High } \\
\text { (9-10 Activities } \\
\text { Supplemented) }\end{array}$} \\
\hline & $\mathrm{f}$ & $\%$ & $\mathrm{f}$ & $\%$ & $\mathrm{f}$ & $\%$ & $\mathrm{f}$ & $\%$ & $\mathrm{f}$ & $\%$ \\
\hline Discovery & 16 & 23.2 & 13 & 18.8 & 26 & 37.7 & 1 & 1.4 & 13 & 18.8 \\
\hline Special Reports & 14 & 20.3 & 18 & 26.1 & 23 & 33.3 & 6 & 8.7 & 8 & 11.6 \\
\hline Reading & 17 & 24.6 & 15 & 21.7 & 19 & 27.5 & 6 & 8.7 & 12 & 17.4 \\
\hline $\begin{array}{l}\text { Interest Learning } \\
\text { Centers } \\
\end{array}$ & 19 & 27.5 & 22 & 31.9 & 10 & 14.5 & 7 & 10.1 & 11 & 15.9 \\
\hline Projects & 11 & 15.9 & 22 & 31.9 & 17 & 24.6 & 8 & 11.6 & 11 & 15.9 \\
\hline Independent Study & 19 & 27.5 & 20 & 29.0 & 16 & 23.2 & 8 & 11.6 & 6 & 8.7 \\
\hline Journal Writing & 26 & 37.7 & 13 & 18.8 & 10 & 14.5 & 13 & 18.8 & 7 & 10.1 \\
\hline Collection & 26 & 37.7 & 12 & 17.4 & 16 & 23.2 & 6 & 8.7 & 9 & 13.0 \\
\hline Students Research & 23 & 33.3 & 12 & 17.4 & 21 & 30.4 & 2 & 2.9 & 11 & 15.9 \\
\hline
\end{tabular}

The degree of utilization of innovative strategies based on the instructional activities supplemented by the faculty members to individualized teaching strategies is very low innovative. 
- Significant Difference in the Perceived Knowledge and Skills of the Faculty Members on the Instructional Activities Across Profile Variables

The difference in the perceived knowledge and skills of the faculty members on the instructional activities across profile variables is not significant.

- Relationship Between Perceived Knowledge and Skills of the Faculty Members on the Instructional Activities and the Degree of Manifestation of the Professional Characteristics of the Faculty Members Handling Professional Education Subjects

The relationship between perceived knowledge and skills of the faculty members on the instructional activities and the degree of manifestation of the professional characteristics of the faculty members handling professional education subjects is significant.

- Relationship Between the Utilization of Innovative Instructional Strategies and Level of Perceived Knowledge and Skills of the Faculty Members of the Innovative Instructional Activities

The relationship between the utilization of brain-based instructional strategies and level of perceived knowledge and skills of the faculty members of the innovative instructional activities is significant. On the other hand, the relationship between the utilization of individualized teaching strategies and level of perceived knowledge and skills of the faculty members of the innovative instructional activities is significant.

- Problems Encountered by the Faculty Members in Utilizing Innovative Instructional Strategies

The top 5 problems encountered by faculty members in utilizing innovative instructional strategies are: The classroom or learning environment is not well equipped with instructional materials with 35 frequency rating; sufficient time is needed in the preparation of innovative instructional materials with 33 frequency rating; utilization of innovative instructional strategies is time consuming with 28 frequency rating; innovative instructional materials are expensive and limited in the market with 26 frequency rating and the school administration supports the utilization of innovative instructional strategies but gives very limited materials with 24 frequency rating out of 69.

\section{Conclusions}

From the preceding findings, the following conclusions are drawn:

The faculty members handling professional education are engaged in teaching in HEI but they have limited experience in teaching professional education course and limited attendance to seminars related to instructional strategies. They possess a high level integrity, decisiveness, resourcefulness, commitment and stress tolerance and highly knowledgeable and skillful on the innovative instructional activities.

The degree of utilization of innovative strategies based on the instructional activities supplemented by the faculty members to brain-based instructional strategies is moderately innovative while the degree of utilization of innovative strategies based on the instructional Activities supplemented by the faculty members to individualized teaching strategies is very low innovative.

There is no significant difference in the perceived knowledge and skills of the faculty members on the instructional activities across profile variables.

There is a significant relationship between perceived knowledge and skills of the faculty members on the instructional activities and the degree of manifestation of the professional characteristics of the faculty members handling professional education subjects.

There is a significant relationship between the utilization of innovative instructional strategies may it be brain-based instructional strategies or individualized teaching strategies and level of perceived knowledge and skills of the faculty members of the innovative instructional activities. 
The problems encountered by faculty members in utilizing innovative instructional strategies are as follows: the classroom or learning environment is not well equipped with instructional materials; sufficient time is needed in the preparation of innovative instructional materials; utilization of innovative instructional strategies is time consuming; innovative instructional materials are expensive and limited in the market; and the school administration supports the utilization of innovative instructional strategies but gives very limited materials.

\section{Recommendations}

Based on the above-mentioned findings and conclusions, the following recommendations are hereby presented:

Faculty members should further enhance and uphold academic excellence in teaching by continuing their studies to graduate and post graduate courses in relation to professional education. They should also enrich their knowledge and skills to instructional strategies by attending seminars or trainings related to instructional strategies on a regular basis.

Faculty members should always set a very high standard of professionalism by demonstrating professional characteristics most especially to integrity, decisiveness, resourcefulness, commitment and stress tolerance.

Faculty members should have an advocacy in updating their knowledge and skills to teaching innovation most especially to instructional activities and strategies.

The school should conduct its own seminar relating to innovative instructional strategies carrying out its nature, significance, implications, benefits, issues and concerns.

The school should invest in re-designing the classrooms using new and up-to-date instructional materials conducive to the present day learning environment brought about by changes due to innovation.

The curriculum planners should add more supplementary time in the preparation of instructional materials before the actual classes start and even to the actual class time to give way for the utilization of innovative instructional strategies.

\section{References}

[1] Aquino, Gaudencio V. (1988) Principles and Methods of Effective Teaching. First Edition. Metro Manila: National Book Store, Inc.

[2] Aquino, Gaudencio V. (1997) Teaching Models, Strategies and Skills. First Edition. Sampaloc, Manila: Rex Book Store, Inc.,

[3] Corpuz, Brenda B. and Salandanan, Gloria G.(2003) Principles and Strategies of Teaching. Metro Manila: Lorimar Publishing Co., Inc.

[4] Corpuz, Brenda B. and Salandanan, Gloria G.(2015) Principles of Teaching 4th Edition. Metro Manila: Lorimar Publishing Co., Inc. (Danielson, 2002, P.72)

[5] Joyce, Bruce, and Weil, Marsha. (200) Models of Teaching. 6th edition. Boston: Allyn and Bacon

[6] Nilson, Linda. (2003) Teaching at Its Best: A Research-Based Resource for College Instructors. 2nd edition. Anker Publishing

[7] Zulueta, Francisco M. (2006) Principles and Methods of Teaching. First Edition. Metro Manila: National Book Store.

[8] http://www.chanrobles.com/bataspambansabilang232.htm\#.UtYRgfvO7Fo

[9] http://teaching.uncc.edu/articles-books/best-practice-articles/course-development/best-practices

[10] http://www.pathways.cu.edu.eg/subpages/training_courses/Research\%20Methods \%208/Chapter4.htm

[11] https://www.oursehero.com/file/6853454/Damodharan-Innovative-Methods/

[12] https://issuu.com/cmi-normay/docs/4632-keeping-music-alive 